\title{
Control of adipocyte differentiation in different fat depots; implications for pathophysiology or therapy
}

\author{
Xiuquan Ma ${ }^{1,2+}$, Paul Lee ${ }^{3 \dagger}$, Donald J. Chisholm ${ }^{3}$ and David E. James ${ }^{4}$ * \\ ${ }^{1}$ Cellular Systems Biology, Diabetes and Metabolism Division, Garvan Institute of Medical Research, Sydney, NSW, Australia \\ ${ }^{2}$ Charles Perkins Centre, School of Molecular Bioscience, The University of Sydney, Sydney, NSW, Australia \\ ${ }^{3}$ Clinical Diabetes, Appetite and Metabolism, Diabetes and Metabolism Division, Garvan Institute of Medical Research, Sydney, NSW, Australia \\ ${ }^{4}$ Charles Perkins Centre, School of Molecular Bioscience, School of Medicine, The University of Sydney, Sydney, NSW, Australia
}

Edited by:

Encarnación Capilla, University of Barcelona, Spain

Reviewed by:

Taisen Iguchi, National Institute for Basic Biology, Japan

Bente Ruyter, Nofima, Norway

*Correspondence:

David E. James, Charles Perkins Centre, School of Molecular

Bioscience, School of Medicine, The University of Sydney, Building D17,

Johns Hopkins Drive Street, Sydney, NSW 2460, Australia

e-mail: david.james@sydney.edu.au

${ }^{+}$Xiuquan Ma and Paul Lee have contributed equally to this work.
Adipocyte differentiation and its impact on restriction or expansion of particular adipose tissue depots have physiological and pathophysiological significance in view of the different functions of these depots. Brown or "beige" fat [brown adipose tissue (BAT)] expansion can enhance thermogenesis, lipid oxidation, insulin sensitivity, and glucose tolerance; conversely expanded visceral fat [visceral white adipose tissue (VAT)] is associated with insulin resistance, low grade inflammation, dyslipidemia, and cardiometabolic risk. The largest depot, subcutaneous white fat [subcutaneous white adipose tissue (SAT)], has important beneficial characteristics including storage of lipid "out of harms way" and secretion of adipokines, especially leptin and adiponectin, with positive metabolic effects including lipid oxidation, energy utilization, enhanced insulin action, and an anti-inflammatory role. The absence of these functions in lipodystrophies leads to major metabolic disturbances. An ability to expand white adipose tissue adipocyte differentiation would seem an important defense mechanism against the detrimental effects of energy excess and limit harmful accumulation of lipid in "ectopic" sites, such as liver and muscle. Adipocyte differentiation involves a transcriptional cascade with PPAR $\gamma$ being most important in SAT but less so in VAT, with increased angiogenesis also critical. The transcription factor, Islet1, is fairly specific to VAT and in vitro inhibits adipocyte differentiation. The physiological importance of Islet1 requires further study. Basic control of differentiation is similar in BAT but important differences include the effect of PGC-1 $\alpha$ on mitochondrial biosynthesis and upregulation of UCP1; also PRDM16 plays a pivotal role in expression of the BAT phenotype. Modulation of the capacity or function of these different adipose tissue depots, by altering adipocyte differentiation or other means, holds promise for interventions that can be helpful in human disease, particularly cardiometabolic disorders associated with the world wide explosion of obesity.

Keywords: adipogenesis, adipocyte, subcutaneous white adipose tissue, visceral white adipose tissue, brown adipose tissue, fat depot, adipocyte differentiation, adipose tissue

\section{INTRODUCTION}

Subcutaneous adipose tissue accounts for about $85 \%$ of all body fat in people of a wide range of adiposity (1). Different human fat depots play contrasting physiological and pathophysiological metabolic roles with brown adipose tissue (BAT) being beneficial, subcutaneous white adipose tissue (SAT) potentially favorable, and visceral white adipose tissue (VAT), together

Abbreviations: ASC-1, Asc-type amino acid transporter 1; AT, adipose tissue; BAT, brown adipose tissue; BMPs, bone morphogenetic proteins; CRP, Creactive protein, pentraxin-related; Dpt, dermatopontin; Ebfl, early B-cell factor 1; FGF21, fibroblast growth factor 21; Hoxc8, homeobox C8; Hoxc9, homeobox C9; IL-6, interleukin 6; IL-8, interleukin 8; Inhbb, inhibin, beta B; Lhx8, LIM homeobox 8; MCP-1, chemokine (C-C motif) ligand 2; MSCs, mesenchymal stem cells; Myf5, myogenic factor 5; MyoD, myogenic differentiation 1; NEFA, non-esterified fatty acids; P2RX5, purinergic receptor P2X, ligand-gated ion channel, 5; PAT2, solute carrier family 36 (proton/amino acid symporter), member 2; PGC-1 $\alpha$, PPAR $\gamma$ coactivator- $1 \alpha$; PRDM16, PRD1-BF-1-RIZ1 homologous domain with "ectopic" tissue lipid, potentially harmful (2). Variation in these different lipid depots may therefore impact significantly on metabolic health. Defining the nature of these variations may improve our understanding of and, hopefully in the future, lead to enhanced therapy or prevention of cardiometabolic disease. Here, we focus particularly on the role of adipocyte differentiation in this regard.

containing protein-16; RBP4, retinol binding protein 4, plasma; SAT, subcutaneous white adipose tissue; Shox2, short stature homeobox 2; SNS, sympathetic nervous system; SRC-1, v-src avian sarcoma (Schmidt-Ruppin A-2) viral oncogene homolog; Tbx15, T-box 15; Tcf2, HNF1 homeobox B; Tcf7l1, transcription factor 7-like 1; TIF2, nuclear receptor coactivator 2 ; TNF- $\alpha$, tumor necrosis factor; Twist-1, twist family bHLH transcription factor 1; UCP1, uncoupling protein 1; VAT, visceral white adipose tissue; WAT, white adipose tissue; Wisp2, WNT1 inducible signaling pathway protein 2; Zfp423, zinc finger protein 423; Zfp521, zinc finger protein 521; Zic1, Zic family member 1 . 


\section{TRANSCRIPTIONAL REGULATION OF ADIPOCYTE DIFFERENTIATION IN DIFFERENT FAT DEPOTS CHARACTERISTICS OF WHITE ADIPOSE TISSUE AND WHITE ADIPOGENESIS \\ White adipose tissue}

The primary metabolic role of white adipose tissue (WAT) is to store nutrients in the form of triglycerides so that it can be released during times of energy demand such as starvation or exercise. Adipose tissue is also recognized as an important endocrine organ and produces and secretes a number of peptides and other factors, which are known as adipokines. WAT is composed primarily of tightly packed, large spherical adipocytes (also called unilocular fat cells as opposed to multilocular adipocytes present in BAT), supported by a richly vascularized loose connective tissue. Adipogenesis, the differentiation of fibroblast-like mesenchymal stem cells (MSCs) into adipocytes, plays a central role in regulation of whole body energy metabolism. At the cellular level, adipogenesis is generally described as a two-step process: a commitment step, wherein committed adipocyte progenitors (or preadipocytes) are generated from multipotent MSCs, and a differentiation step, wherein pre-adipocytes acquire the features of mature, functional adipocytes (3).

\section{Recruitment of new fat progenitor cells}

Expansion and renewal of the white adipocyte pool in WAT is believed to rely on proliferation and self-renewal of mesenchymal precursor cells (4) that we term white adipocyte progenitors (WAPs). WAPs reside within the population of adipose stromal cells (ASCs) (5). Several studies have demonstrated that perivascular cells isolated from adipose tissue may harbor white fat progenitors (6-8). A study using PPAR $\gamma$ as a preadipocyte marker found that WAPs reside in the mural cell compartment of the adipose vasculature (9). Similarly, genetic labeling of a transcription factor that is enriched in fat cell precursors Zfp423 demonstrates a perivascular origin of pre-adipocytes, and this transcription factor is both necessary and sufficient for the development of a common precursor of white and brown adipocytes $(10,11)$. VE-cadherin (vascular endothelial) promoter-driven lineage-tracing experiments provide an independent line of evidence that both pericytes and murine endothelial cells can differentiate into pre-adipocytes and adipocytes (12).

\section{Commitment}

More light has been shed on adipocyte commitment studies in recent years. Several important transcription factors have been identified as regulators of preadipocyte determination, including Zfp423, Tcf7l1, and Ebf1 as positive transcription factors; and Zfp521, Wisp2 as negative transcription factors. Zfp423 induces adipose lineage commitment by amplifying the effects of the bone morphogenetic proteins (BMPs) signaling pathway, which is required for adipocyte lineage commitment (10,13). Ebf1, a Zfp423 interactor $(14,15)$, is required for the generation of adipocyte progenitors $(16,17)$. However, the role of the interaction between Ebf1 and Zfp423 in preadipocyte commitment remains unknown. Zfp521 is a factor related to Zfp423, which represses preadipocyte commitment at least in part through direct inhibition of Ebf1 and subsequent repression of Zfp423 expression (17).
Wisp2 binds directly to Zfp423 in the cytosol to inhibit its activity and negatively regulates preadipocyte commitment in mesenchymal precursor cells (18). In addition, extracellular WNT/WISP2 also regulates differentiation by preventing PPAR $\gamma$ activation via an unknown mechanism. Tcf7l1 acts in a different manner by responding to the confluence of the cells, mediating changes in structural proteins that regulate differentiation and in turn influence adipose commitment (19). What is interesting is that PPAR $\gamma$ activation is involved in mediating the effect of all currently identified commitment factors, which suggests that PPAR $\gamma$ is essential for preadipocyte determination in addition to its well known role as a "master regulator" of terminal adipocyte differentiation (20).

\section{Differentiation}

The transcriptional cascade that promotes differentiation has been well studied. Terminal differentiation is controlled by a tightly regulated transcriptional cascade where the transcription factors activate or repress the expression of each other in a sequential manner or by positive or negative feedback loops. Key players in this transcriptional cascade include CCAAT/enhancer-binding protein $(\mathrm{C} / \mathrm{EBP})$ family members (i.e., $\mathrm{C} / \mathrm{EBP} \alpha, \mathrm{C} / \mathrm{EBP} \beta$, and $\mathrm{C} / \mathrm{EBP} \delta$ ), KLFs, CREB, Krox20, and PPAR $\gamma(20-22) . \mathrm{C} / \mathrm{EBP} \beta$ and $\delta$ act early in the terminal differentiation to induce the expression of PPAR $\gamma$ and $\mathrm{C} / \mathrm{EBP} \alpha$. Differentiation is "locked in" by a positive feedback loop between PPAR $\gamma$ and $\mathrm{C} / \mathrm{EBP} \alpha(23,24)$; a second positive feedback loop between PPAR $\gamma$ and $\mathrm{C} / \mathrm{EBP} \beta$ reinforces the decision toward differentiation (25).

\section{CHARACTERISTICS OF BROWN ADIPOSE TISSUE AND BROWN ADIPOGENESIS \\ Brown adipose tissue}

Recent studies have revisited the role of BAT in adults (26). Unlike WAT, BAT expresses the mitochondrial protein uncoupling protein 1 (UCP1) that enables dissociation of cellular respiration from ATP utilization, resulting in the release of stored electrochemical energy as heat, thereby fulfilling its role as a thermogenic organ. Contrary to the traditional view that BAT and WAT share a common developmental origin, recent studies revealed several unexpected developmental lineages giving rise to BAT and "brown fat-like" cells, orchestrated by novel transcriptional regulators.

\section{PGC-1 $\alpha$ and PRDM16}

Brown adipocyte differentiation begins with commitment to adipogenesis by a cascade of transcriptional factor interactions similar to white adipocytes (see Characteristics of White Adipose Tissue and White Adipogenesis). However, $\operatorname{PAAR} \gamma$ coactivator-1alpha $(\mathrm{PGC}-1 \alpha)$, the master regulator of mitochondrial biogenesis, is crucial in brown adipogenesis. PGC- $1 \alpha$ drives the synthesis of UCP1 by stimulating its promoter (27). Recent studies have identified an array of nuclear receptor co-regulators that also stimulate brown adipogenesis, including $S R C-1, T I F 2$, and Twist-1, which have been reviewed in detail (28).

A pivotal regulator of brown adipogenesis is PRD1-BF-1-RIZ1 homologous domain containing protein-16 (PRDM16). Ectopic expression of PRDM16 in fibroblasts, myoblasts, or pre-adipocytes is sufficient to induce the full brown fat transcriptome, includ-

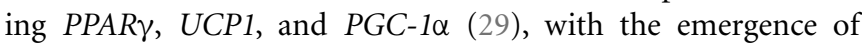


a brown fat phenotype and function, including mitochondrial biogenesis and respiratory uncoupling. In contrast, depletion of PRDM16 in brown fat cells causes a near total loss of the brown characteristics (30).

\section{Developmental origins}

Ablation of PRDM16 increases the expression of MyoD, myogenin, myosin light chain, and muscle creatine kinase, together with morphological transformation of pre-adipocytes into myoblasts (31). These results are concordant with the identification of Myf5, a gene previously assumed to be expressed almost exclusively in committed skeletal muscle precursors, in interscapular BAT (29). Muscle-specific microRNAs are also expressed in brown but not in white adipocytes (32). Collectively, these results have underscored distinct origins of BAT and WAT, and consolidated the currently accepted view that classic brown adipocytes are more closely related to skeletal muscle than white adipocytes.

In addition to skeletal muscle, increasing evidence suggests that brown adipocytes may also be derived from other sources. Upon cold exposure, brown fat-like cells emerge within WAT in rodents $(33,34)$. These cells express UCP1 at levels indistinguishable from classic brown adipocytes. These brown fat-like cells within WAT are referred to as "brite" (brown-in-white) (33) or beige adipocytes (35). The developmental origin of brite/beige cells is a subject of ongoing debate. Based on the absence of an increase in cell number upon cold acclimatization, some argue that brite/beige cells arise from direct transformation or transdifferentiation from white adipocytes (36). Conversely, other studies support the presence of distinct inducible brite/beige precursors within WAT, which may also be $M y f 5$ positive (37).

\section{Markers of different fat depots}

A panel of molecular markers has been identified that delineate brown, white, and brite/beige adipocytes: $L h x 8$ and $Z i c 1$ for brown, Tbx15 for brown/brite, Hoxc9 and Shox2 for brite/beige, Hoxc8, Inhbb, and $D p t$ for brite/white, and $T c f 21$ for white adipocytes (38). Very recently, surface markers of each adipocyte type have been discovered; ASC-1, PAT2, and P2RX5, for white, beige/brite, and brown adipocytes, respectively (39).

In summary, brown adipocytes display a stronger myogenic signature than beige/brite adipocytes, while myogenic-related genes are absent in white adipocytes, implying a non-myogenic origin of brite adipocytes. This paradigm continues to evolve and is an area of intense research, with new evidence pointing to yet more diverse origins, such as brown adipocytes arising from hematopoietic stem cells within bone marrow (40) and brite/beige adipocytes differentiating from smooth muscle-like cells surrounding blood vessels (41).

\section{REGULATION OF ADIPOSE TISSUE EXPANSION IN DIFFERENT FAT DEPOTS GENETIC INFLUENCE}

There is a strong genetic contribution to overall adiposity (42), which is largely determined by SAT, so there are likely to be genes, which have a strong influence on adipose tissue differentiation/expansion as well as appetite regulation, though human monogenic forms of obesity of which the MC4R mutations are the commonest, appear mainly related to appetite and energy balance $(2,43)$. PPAR $\gamma$ mutations are an exception. The importance of PPAR $\gamma$ in regulating SAT is demonstrated by the effect of PPAR $\gamma$ agonists in causing expansion of the subcutaneous, but not visceral, fat compartment (44), and rare loss-offunction $\operatorname{PPAR} \gamma$ mutations cause reduced subcutaneous (particularly gluteal) fat (45). VAT adipocytes express the PPAR $\gamma$ receptor in reasonable abundance but PPAR $\gamma$ is less able to promote adipocyte differentiation in vitro in adipose tissue from this compartment (46).

In fact, some ethnic groups, including Southern Indians and Australian aboriginals, seem to have a reduced ability to expand their peripheral subcutaneous fat in the face of energy surplus (4750). The genetic control of this expansion, or lack thereof, is poorly understood although Lamin A must have a role as mutations in some regions of this gene cause reduced adipocyte differentiation in vitro and congenital lipodystrophy (51).

Again there is evidence from twin and other studies for strong genetic control over central abdominal (including visceral) fat (52, 53 ) independent of overall adiposity but without a clear understanding of the molecular mechanisms. We have reported the presence of the transcription factor Islet1 (important for development of islets, cardiac tissue, and neurons) in the stromovascular (preadipocyte-containing) fraction of VAT but not SAT and its expression is correlated in animals and humans with leanness (54). We have also recently demonstrated the ability of Islet1 to inhibit 3T3-L1 preadipocyte differentiation in vitro at least in part via downregulation of bone morphogenic protein 4 (BMP4) (55). Further work will be needed to determine whether Islet1 is a significant regulator of visceral adiposity in humans.

In contrast to the well-defined interscapular location of BAT in rodents, human BAT/beige fat is located in a fascial plane extending from the cervical to the supraclavicular/axillary regions, with smaller depots around the mediastinum, as well as pericardial, paravertebral, and suprarenal regions (56). In other words, both SAT (i.e., supraclavicular BAT) and VAT (i.e., suprarenal BAT) could harbor adipocytes with BAT-like features. Interestingly, adipose-specific ablation of PRDM16 inhibits formation of beige adipocytes in SAT of cold-exposed rodents (57). These animals rapidly gained SAT upon high fat feeding yet the excess "SAT" displayed a gene signature typical of VAT, characterized by inflammation and macrophage infiltration. These findings suggest complex interplay between adipose composition and location, and brown/beige/white adipogenesis may regulate adipose function in depot-specific manner.

\section{HORMONAL INFLUENCE}

Hormonal influences (2) are important as indicated by the effect of estrogen increasing SAT (especially gluteal). Cortisol in excess increases central fat (both SAT and VAT) and growth hormone reduces subcutaneous adiposity. Again the mechanisms for these effects are not fully understood although increased lipolysis may be the predominant effect of growth hormone (58).

Estrogen not only favors expansion of SAT but also limits VAT (59) and the effect is therefore lost post-menopause (59). To what extent this action is related to modulation of adipocyte differentiation in the VAT compartment is unclear. 
Numerous hormones modulate BAT activity. For example, thyroid hormone (60) and estradiol (61) stimulate mitochondrial biogenesis and brown adipogenesis, while testosterone (62) and cortisol (63) inhibit BAT proliferation and differentiation. Intriguingly, eosinophils through atypical macrophages also stimulate brite/beige adipogenesis in rodents (64). Recently, novel cytokines including irisin (65), fibroblast growth factor 21 (FGF21) (66), BMPs (67), and Meterorin-like (68) have been discovered, which independently regulate BAT and/or beige/brite fat function beyond classic SNS and/or pituitary-thyroid-adrenal axes, thereby opening new directions in BAT-based therapeutics (see Brown Adipose Tissue).

\section{ENVIRONMENTAL INFLUENCE}

Exercise training (particularly aerobic) also reduces VAT and hepatic steatosis (69) to a greater extent than SAT $(70,71)$, presumably related to the greater lipolytic response of VAT adipocytes and simple depletion of triglyceride; however, an effect on limiting adipocyte differentiation/expansion is an additional possibility.

Studies have confirmed the presence of BAT and brown fat-like cells in humans (56) (see Brown Adipose Tissue). Whole body BAT function can therefore be expanded either through recruitment of classic BAT and/or brite/beige fat induction (i.e., fat browning). Cold exposure is the best-established mechanism for expanding BAT and beige depots: acute cold exposure elevates UCP1 mRNA expression in both interscapular BAT and beige/brite fat within WAT, while prolonged cold exposure induces BAT hypertrophy and hyperplasia, and induces beige/brite adipogenesis (72). Although classically viewed as the mediator of cold exposure, the sympathetic nervous system (SNS) may not be the sole driver of cold-induced BAT recruitment.

Pharmacological studies have demonstrated remarkable proliferation/expansion of interscapular BAT during chronic betaagonist exposure (73), and beige/brite adipogenesis can be induced within WAT following $\beta 3$-agonist treatment, similar to results observed in cold exposure studies, thus supporting the role of SNS as a cold-mediator. However, cold may have a direct stimulatory effect on BAT, independent of SNS. Cold exposure, but not non-selective $\beta$-agonists in therapeutic dosage, activates BAT in humans, suggesting probable presence of non-SNS BAT-activating factors exerting effects during cold exposure. UCP1 expression is also increased in adipocytes exposed to cold temperature in vitro (74). The cell-autonomous response to cold further supports the presence of direct cold-mediated BAT expansion and/or fat-browning mechanisms.

\section{IMPLICATIONS FOR PATHOPHYSIOLOGY/THERAPY}

Studies by our own and other groups have shown that abdominal obesity is associated with several negative effects including insulin resistance, cardiovascular disease, inflammation, and various cancers (75-78), which indicates that expansion of visceral fat is adverse, and conversely reduction of visceral fat mass should be beneficial.

Several factors may contribute to the adverse effects of VAT including a hyperactive secretome, inflammation, lipolysis, and transmission of fatty acids via the portal vein to the liver. Adipose tissue is an endocrine organ that secretes numerous proteins (adipokines) and lipids that have potent metabolic effects on other organs including muscle, liver, and brain $(79,80)$. The differential secretion of adipokines may account for the differing metabolic consequences of visceral vs. subcutaneous adiposity. Compared with SAT, VAT secretes lower amounts of metabolically beneficial adipokines including leptin and adiponectin, but higher amounts of detrimental or proinflammatory adipokines such as RBP4, TNF- $\alpha$, MCP-1, IL-8, and IL-6 (81-83). Although adiponectin is expressed and secreted mainly by subcutaneous adipose tissue, lower adiponectin concentrations are related to visceral fat accumulation $(84,85)$. CRP levels are significantly related to waist circumference (WC), while MCP-1 is more highly associated with VAT compared with SAT $(86,87)$. Therefore, abdominal obesity is associated with reduced levels of adiponectin, and increased levels of inflammatory adipokines. MCP-1 can induce macrophage infiltration and activation in adipose tissue and these adipose tissue macrophages are postulated to be a major contributor to obesityassociated chronic low grade inflammation, which may contribute to the pathogenesis of obesity-induced insulin resistance $(88,89)$. Although insulin resistance has also been shown to occur independently of changes in AT inflammation (90), in which case it is possible that AT macrophage infiltration is serving an alternate function such as the clearance of dead adipocytes (91), which is an initial remodeling event required for AT regeneration and expansion in response to energy surfeit (92).

Lipolytic regulation also differs between VAT and SAT in that visceral adipocytes are more metabolically active; they have a greater lipolytic capacity (93-95) and, compared with subcutaneous abdominal or femoral adipose cells, they display greater catecholamine induced lipolysis and reduced suppression of lipolysis in response to both insulin and $\alpha 2$-adrenergic agonists (96, 97). The increased lipolytic capacity of VAT causes increased release of FFAs from VAT, potentially increasing hepatic gluconeogenesis (98) and contributing to ectopic lipid deposition in a range of tissues, contributing to insulin resistance (99). Fat accumulation in the liver (100) or muscle (101) is tightly associated with insulin resistance and type 2 diabetes. However, there is evidence that visceral fat is not as important as subcutaneous fat in supplying FFAs to the liver in lean or in most obese persons (102, 103). Additional studies are needed to definitively determine the relationship between individual abdominal fat depots and insulin resistance.

\section{SUBCUTANEOUS WHITE ADIPOSE TISSUE}

Although obesity, with increased SAT, is metabolically harmful, a lack of adipose tissue, especially SAT, can be as bad or worse. Various congenital or acquired lipodystrophies are characterized by hepatic steatosis, dyslipidemia, and insulin resistance with increased risk of diabetes $(2,104)$. This appears attributable to a combination of diversion of lipid away from an inadequate adipose tissue reservoir to "ectopic sites" such as liver and muscle, and also to a lack of secretion of the "favorable" adipokines leptin and adiponectin; the low leptin levels explain increased appetite and inappropriately positive energy balance and reduced levels of both adipokines contribute to reduced activity of AMP-activated protein kinase (AMPK), which promotes lipid oxidation (2). Human lipodystrophies used to be rare but HIV lipodystrophy, strongly 
associated with the earlier HIV antiviral drugs, has been common in subjects treated for HIV (105); again the molecular mechanisms involved are not clearly understood but may involve disturbances of adipocyte PPAR $\gamma$ and GLUT4 activity.

Conversely, PPAR $\gamma$ agonists such as pio- and rosiglitazone expand SAT, which appears to "sequester" excess lipid and lower circulating non-esterified fatty acids (NEFA) levels. The resulting metabolic improvement is also contributed to by increased adiponectin secretion; the net result being improved insulin sensitivity and prevention/improvement of type 2 diabetes (106). Of course the weight gain has negative musculoskeletal and cosmetic implications and the enhanced adipocyte differentiation may be at the expense of reduced osteoblast differentiation in bone with consequent reduction of bone density (107).

In treating ordinary obesity, energy restriction is paramount but increased exercise assists loss of adipose tissue rather than lean mass (2). The importance of energy restriction rather than simple reduction of SAT mass was clearly demonstrated by the complete lack of metabolic benefit from removal of $\sim 10 \mathrm{~kg}$ of subcutaneous fat in obese subjects by liposuction (108). Thus, simple depletion of the SAT "reservoir" is of no value and the benefit of energy restriction by diet, bariatric surgery, or other means would seem to be dependent on reduction of hepatic, intramyocellular, and visceral lipid. In regard to the latter, surgical VAT resection in obese insulin resistant rats generates significant metabolic improvement (109) but evidence in humans is conflicting $(2,110)$.

So where do we go in using our knowledge of adipocyte differentiation to extend therapy beyond energy restriction? As indicated above, measures to reduce the SAT depot may do more harm than good; however, some animal models with reduced SAT do have a favorable phenotype, e.g., the c-Cbl deletion, where there is increased energy expenditure (111) and some genetic manipulations inhibiting adipose angiogenesis may improve insulin sensitivity/glucose tolerance (112) but some have the reverse effect (113) for reasons that are not clear but may include effects on appetite. Thus, with an increased knowledge of the molecular metabolism of these models - especially feedback effects on orexigenic pathways - it may be possible to design pharmacotherapy to reduce overall or subcutaneous fat, gain a favorable metabolic outcome, and get the musculoskeletal benefit of reduced weight.

\section{VISCERAL WHITE ADIPOSE TISSUE}

It is unclear if pharmacotherapy to specifically reduce VAT would be possible but VAT has a number of developmental genes, as well as Islet1, which are different from those in SAT $(114,115)$ so in theory such agents could be developed. The metabolic response would be uncertain but interesting and informative.

\section{BROWN ADIPOSE TISSUE}

One exciting prospect in this area is to increase the amount and/or activity of brown or "beige" fat. Animals with high BAT and/or beige/brite abundance are protected against obesity, diabetes, hepatic steatosis, and hyperlipidemia. BAT and/or beige/brite fat expanding therapeutic strategies are attractive in the combat against obesity and related disorders in humans.

In this regard, cold acclimation is an effective method of BAT recruitment in humans. Mild cold exposure at $16-19^{\circ} \mathrm{C}$ for
2-6 weeks increases BAT volume and activity in adults (116-118), augmenting cold-induced thermogenesis $(116,117)$, and resulting in reduced adiposity (117) as well as enhancement of post-prandial insulin sensitivity (118). Unfortunately, the natural tendency for thermal comfort could limit the applicability of cold exposure as a BAT expanding strategy.

Pharmacological BAT activation is an attractive alternative. The disappointing results of $\beta 3$-agonist studies a decade ago on weight loss (119) could stem from the relatively low expression of $\beta 3$ receptors in human BAT. The use of non-selective $\beta$-agonists for BAT expanding purposes is limited by inadvertent crossstimulation of cardiac $\beta$-receptors. Non-SNS therapeutics based on newly discovered fat browning and/or BAT-activating cytokines have strong potential (56). FGF21 and irisin are particularly relevant as they are potent endocrine human BAT activators that are stimulated by cold exposure in adults (120). Whether FGF21 and irisin can be transformed into injectable recombinant proteins for obesity and/or diabetes treatment is under active research at present. It is important to point out that in all of these studies it is not possible to exclude non-cell autonomous effects for all of these perturbations including a central effect to repress food intake.

\section{CONCLUDING REMARIKS}

In summary, fat distribution (e.g., VAT vs. SAT) and composition (e.g., WAT vs. BAT) are both metabolic health determinants with therapeutic implications. Although adipogenesis dictates mature adipocyte phenotypes, adipogenesis at the tissue level defines fat distribution, and ultimately modulates organ function. Pinpointing crossroads in adipogenic checkpoints governing SAT/VAT expansion and WAT/BAT differentiation may ultimately open novel avenues in obesity treatment by sculpting a metabolically favorable whole body adipose distributional/compositional phenotype.

\section{ACKNOWLEDGMENTS}

This work was supported by the National Health and Medical Research Council (NHMRC) program grant GNT535921 to David E. James, and Donald J. Chisholm. David E. James is an NHMRC Senior Principal Research Fellow.

\section{REFERENCES}

1. Frayn KN, Karpe F. Regulation of human subcutaneous adipose tissue blood flow. Int J Obes (Lond) (2014) 38:1019-26. doi:10.1038/ijo.2013.200

2. Hocking S, Samocha-Bonet D, Milner KL, Greenfield JR, Chisholm DJ. Adiposity and insulin resistance in humans: the role of the different tissue and cellular lipid depots. Endocr Rev (2013) 34:463-500. doi:10.1210/er.2012-1041

3. Rosen ED, Spiegelman BM. What we talk about when we talk about fat. Cell (2014) 156:20-44. doi:10.1016/j.cell.2013.12.012

4. Kras KM, Hausman DB, Hausman GJ, Martin RJ. Adipocyte development is dependent upon stem cell recruitment and proliferation of preadipocytes. Obes Res (1999) 7:491-7. doi:10.1002/j.1550-8528.1999.tb00438.x

5. Gimble JM, Katz AJ, Bunnell BA. Adipose-derived stem cells for regenerative medicine. Circ Res (2007) 100:1249-60. doi:10.1161/01.RES.0000265074. 83288.09

6. Amos PJ, Shang H, Bailey AM, Taylor A, Katz AJ, Peirce SM. IFATS collection: the role of human adipose-derived stromal cells in inflammatory microvascular remodeling and evidence of a perivascular phenotype. Stem Cells (2008) 26:2682-90. doi:10.1634/stemcells.2008-0030

7. Crisan M, Yap S, Casteilla L, Chen CW, Corselli M, Park TS, et al. A perivascular origin for mesenchymal stem cells in multiple human organs. Cell Stem Cell (2008) 3:301-13. doi:10.1016/j.stem.2008.07.003 
8. Traktuev DO, Merfeld-Clauss S, Li J, Kolonin M, Arap W, Pasqualini R, et al. A population of multipotent CD34-positive adipose stromal cells share pericyte and mesenchymal surface markers, reside in a periendothelial location, and stabilize endothelial networks. Circ Res (2008) 102:77-85. doi:10.1161/ CIRCRESAHA.107.159475

9. Tang W, Zeve D, Suh JM, Bosnakovski D, Kyba M, Hammer RE, et al. White fat progenitor cells reside in the adipose vasculature. Science (2008) 322:583-6. doi:10.1126/science.1156232

10. Gupta RK, Arany Z, Seale P, Mepani RJ, Ye L, Conroe HM, et al. Transcriptional control of preadipocyte determination by Zfp423. Nature (2010) 464:619-23. doi:10.1038/nature08816

11. Gupta RK, Mepani RJ, Kleiner S, Lo JC, Khandekar MJ, Cohen P, et al. Zfp423 expression identifies committed preadipocytes and localizes to adipose endothelial and perivascular cells. Cell Metab (2012) 15:230-9. doi:10.1016/j. cmet.2012.01.010

12. Tran KV, Gealekman O, Frontini A, Zingaretti MC, Morroni M, Giordano A, et al. The vascular endothelium of the adipose tissue gives rise to both white and brown fat cells. Cell Metab (2012) 15:222-9. doi:10.1016/j.cmet. 2012.01.008

13. Huang HY, Song TJ, Li X, Hu LL, He Q, Liu M, et al. BMP signaling pathway is required for commitment of C3H10T1/2 pluripotent stem cells to the adipocyte lineage. Proc Natl Acad Sci U S A (2009) 106:12670-5. doi:10.1073/pnas.0906266106

14. Tsai RY, Reed RR. Identification of DNA recognition sequences and protein interaction domains of the multiple-Zn-finger protein Roaz. Mol Cell Biol (1998) 18:6447-56.

15. Hata A, Seoane J, Lagna G, Montalvo E, Hemmati-Brivanlou A, Massague J. OAZ uses distinct DNA- and protein-binding zinc fingers in separate BMPSmad and Olf signaling pathways. Cell (2000) 100:229-40. doi:10.1016/S00928674(00)81561-5

16. Festa E, Fretz J, Berry R, Schmidt B, Rodeheffer M, Horowitz M, et al. Adipocyte lineage cells contribute to the skin stem cell niche to drive hair cycling. Cell (2011) 146:761-71. doi:10.1016/j.cell.2011.07.019

17. Kang S, Akerblad P, Kiviranta R, Gupta RK, Kajimura S, Griffin MJ, et al. Regulation of early adipose commitment by zfp521. PLoS Biol (2012) 10:e1001433. doi:10.1371/journal.pbio.1001433

18. Hammarstedt A, Hedjazifar S, Jenndahl L, Gogg S, Grunberg J, Gustafson B, et al. WISP2 regulates preadipocyte commitment and PPARgamma activation by BMP4. Proc Natl Acad Sci U S A (2013) 110:2563-8. doi:10.1073/pnas. 1211255110

19. Cristancho AG, Schupp M, Lefterova MI, Cao S, Cohen DM, Chen CS, et al. Repressor transcription factor 7-like 1 promotes adipogenic competency in precursor cells. Proc Natl Acad Sci U S A (2011) 108:16271-6. doi:10.1073/pnas.1109409108

20. Farmer SR. Transcriptional control of adipocyte formation. Cell Metab (2006) 4:263-73. doi:10.1016/j.cmet.2006.07.001

21. Rosen ED, MacDougald OA. Adipocyte differentiation from the inside out. Nat Rev Mol Cell Biol (2006) 7:885-96. doi:10.1038/nrm2066

22. Siersbaek R, Nielsen R, Mandrup S. Transcriptional networks and chromatin remodeling controlling adipogenesis. Trends Endocrinol Metab (2012) 23:56-64. doi:10.1016/j.tem.2011.10.001

23. Wu Z, Rosen ED, Brun R, Hauser S, Adelmant G, Troy AE, et al. Crossregulation of $\mathrm{C} / \mathrm{EBP}$ alpha and PPAR gamma controls the transcriptional pathway of adipogenesis and insulin sensitivity. Mol Cell (1999) 3:151-8. doi:10.1016/S1097-2765(00)80306-8

24. Rosen ED, Hsu CH, Wang X, Sakai S, Freeman MW, Gonzalez FJ, et al. $\mathrm{C} / \mathrm{EBPalpha}$ induces adipogenesis through PPARgamma: a unified pathway. Genes Dev (2002) 16:22-6. doi:10.1101/gad.948702

25. Park BO, Ahrends R, Teruel MN. Consecutive positive feedback loops create a bistable switch that controls preadipocyte-to-adipocyte conversion. Cell Rep (2012) 2:976-90. doi:10.1016/j.celrep.2012.08.038

26. Nedergaard J, Bengtsson T, Cannon B. Three years with adult human brown adipose tissue. Ann N Y Acad Sci (2010) 1212:E20-36. doi:10.1111/j.1749-6632. 2010.05905.x

27. Richard D, Picard F. Brown fat biology and thermogenesis. Front Biosci (Landmark Ed) (2011) 16:1233-60. doi:10.2741/3786

28. Kajimura S, Seale P, Spiegelman BM. Transcriptional control of brown fat development. Cell Metab (2010) 11:257-62. doi:10.1016/j.cmet.2010.03.005
29. Seale P, Bjork B, Yang W, Kajimura S, Chin S, Kuang S, et al. PRDM16 controls a brown fat/skeletal muscle switch. Nature (2008) 454:961-7. doi:10.1038/ nature 07182

30. Seale P, Kajimura S, Yang W, Chin S, Rohas LM, Uldry M, et al. Transcriptional control of brown fat determination by PRDM16. Cell Metab (2007) 6:38-54. doi:10.1016/j.cmet.2007.06.001

31. Kajimura S, Seale P, Kubota K, Lunsford E, Frangioni JV, Gygi SP, et al. Initiation of myoblast to brown fat switch by a PRDM16-C/EBP-beta transcriptional complex. Nature (2009) 460:1154-8. doi:10.1038/nature08262

32. Walden TB, Timmons JA, Keller P, Nedergaard J, Cannon B. Distinct expression of muscle-specific microRNAs (myomirs) in brown adipocytes. J Cell Physiol (2009) 218:444-9. doi:10.1002/jcp.21621

33. Petrovic N, Walden TB, Shabalina IG, Timmons JA, Cannon B, Nedergaard J. Chronic peroxisome proliferator-activated receptor gamma (PPARgamma) activation of epididymally derived white adipocyte cultures reveals a population of thermogenically competent, UCP1-containing adipocytes molecularly distinct from classic brown adipocytes. J Biol Chem (2010) 285:7153-64. doi:10.1074/jbc.M109.053942

34. Walden TB, Hansen IR, Timmons JA, Cannon B, Nedergaard J. Recruited vs. nonrecruited molecular signatures of brown, "brite," and white adipose tissues. Am J Physiol Endocrinol Metab (2012) 302:E19-31. doi:10.1152/ajpendo.00249. 2011

35. Wu J, Bostrom P, Sparks LM, Ye L, Choi JH, Giang AH, et al. Beige adipocytes are a distinct type of thermogenic fat cell in mouse and human. Cell (2012) 150:366-76. doi:10.1016/j.cell.2012.05.016

36. Barbatelli G, Murano I, Madsen L, Hao Q, Jimenez M, Kristiansen K, et al. The emergence of cold-induced brown adipocytes in mouse white fat depots is determined predominantly by white to brown adipocyte transdifferentiation. Am J Physiol Endocrinol Metab (2010) 298:E1244-53. doi:10.1152/ajpendo. 00600.2009

37. Lee YH, Petkova AP, Mottillo EP, Granneman JG. In vivo identification of bipotential adipocyte progenitors recruited by beta3-adrenoceptor activation and high-fat feeding. Cell Metab (2012) 15:480-91. doi:10.1016/j.cmet.2012.03.009

38. Harms M, Seale P. Brown and beige fat: development, function and therapeutic potential. Nat Med (2013) 19:1252-63. doi:10.1038/nm.3361

39. Ussar S, Lee KY, Dankel SN, Boucher J, Haering MF, Kleinridders A, et al. ASC-1, PAT2, and P2RX5 are cell surface markers for white, beige, and brown adipocytes. Sci Transl Med (2014) 6:247ra103. doi:10.1126/scitranslmed. 3008490

40. Nishio M, Yoneshiro T, Nakahara M, Suzuki S, Saeki K, Hasegawa M, et al. Production of functional classical brown adipocytes from human pluripotent stem cells using specific hemopoietin cocktail without gene transfer. Cell Metab (2012) 16:394-406. doi:10.1016/j.cmet.2012.08.001

41. Long JZ, Svensson KJ, Tsai L, Zeng X, Roh HC, Kong X, et al. A smooth musclelike origin for beige adipocytes. Cell Metab (2014) 19:810-20. doi:10.1016/j. cmet.2014.03.025

42. O'Rahilly S, Farooqi IS. Human obesity as a heritable disorder of the central control of energy balance. Int J Obes (2008) 32:S55-61. doi:10.1038/ijo.2008. 239

43. Farooqi IS, Keogh JM, Yeo GS, Lank EJ, Cheetham T, O’Rahilly S. Clinical spectrum of obesity and mutations in the melanocortin 4 receptor gene. $N$ Engl J Med (2003) 348:1085-95. doi:10.1056/NEJMoa022050

44. Carey DG, Cowin GJ, Galloway GJ, Jones NP, Richards JC, Biswas N, et al. Effect of rosiglitazone on insulin sensitivity and body composition in type 2 diabetic patients. Obes Res (2002) 10:1008-15. doi:10.1038/oby.2002.137

45. Semple RK, Chatterjee VK, O'Rahilly S. PPAR gamma and human metabolic disease. J Clin Invest (2006) 116:581-9. doi:10.1172/JCI28003

46. Adams M, Montague CT, Prins JB, Holder JC, Smith SA, Sanders L, et al. Activators of peroxisome proliferator-activated receptor gamma have depotspecific effects on human preadipocyte differentiation. J Clin Invest (1997) 100:3149-53. doi:10.1172/JCI119870

47. Piers LS, Rowley KG, Soares MJ, O’Dea K. Relation of adiposity and body fat distribution to body mass index in Australians of Aboriginal and European ancestry. Eur J Clin Nutr (2003) 57:956-63. doi:10.1038/sj.ejcn.1601630

48. Kondalsamy-Chennakesavan S, Hoy WE, Wang Z, Briganti E, Polkinghorne K, Chadban S, et al. Anthropometric measurements of Australian Aboriginal adults living in remote areas: comparison with nationally representative findings. Am J Hum Biol (2008) 20:317-24. doi:10.1002/ajhb.20729 
49. Kondalsamy-Chennakesavan S, Hoy WE, Wang Z, Shaw J. Quantifying the excess risk of type 2 diabetes by body habitus measurements among Australian aborigines living in remote areas. Diabetes Care (2008) 31:585-6. doi:10.2337/dc07-1156

50. Nyamdorj R, Pitkaniemi J, Tuomilehto J, Hammar N, Stehouwer CD, Lam $\mathrm{TH}$, et al. Ethnic comparison of the association of undiagnosed diabetes with obesity. Int J Obes (Lond) (2010) 34:332-9. doi:10.1038/ijo.2009.225

51. Oldenburg AR, Delbarre E, Thiede B, Vigouroux C, Collas P. Deregulation of Fragile X-related protein 1 by the lipodystrophic lamin A p.R482W mutation elicits a myogenic gene expression program in preadipocytes. Hum Mol Genet (2014) 23:1151-62. doi:10.1093/hmg/ddt509

52. Carey DG, Nguyen TV, Campbell LV, Chisholm DJ, Kelly P. Genetic influences on central abdominal fat: a twin study. Int J Obes Relat Metab Disord (1996) 20:722-6.

53. Samaras K, Spector TD, Nguyen TV, Baan K, Campbell LV, Kelly PJ. Independent genetic factors determine the amount and distribution of fat in women after the menopause. J Clin Endocrinol Metab (1997) 82:781-5. doi:10.1210/jc.82.3.781

54. Li H, Heilbronn LK, Hu D, Poynten AM, Blackburn MA, Shirkhedkar DP, et al. Islet-1: a potentially important role for an islet cell gene in visceral fat. Obesity (Silver Spring) (2008) 16:356-62. doi:10.1038/oby.2007.76

55. Ma X, Yang P, Kaplan WH, Lee BH, Wu LE, Yang JY, et al. ISL1 regulates peroxisome proliferator-activated receptor gamma activation and early adipogenesis via bone morphogenetic protein 4-dependent and -independent mechanisms. Mol Cell Biol (2014) 34:3607-17. doi:10.1128/MCB.00583-14

56. Lee P, Swarbrick MM, Ho KK. Brown adipose tissue in adult humans: a metabolic renaissance. Endocr Rev (2013) 34:413-38. doi:10.1210/er.2012-1081

57. Cohen P, Levy JD, Zhang Y, Frontini A, Kolodin DP, Svensson KJ, et al. Ablation of PRDM16 and beige adipose causes metabolic dysfunction and a subcutaneous to visceral fat switch. Cell (2014) 156:304-16. doi:10.1016/j.cell. 2013.12.021

58. Ho KK, O'Sullivan AJ, Hoffman DM. Metabolic actions of growth hormone in man. Endocr J (1996) 43(Suppl):S57-63. doi:10.1507/endocrj.43.Suppl_S57

59. Poehlman ET, Toth MJ, Gardner AW. Changes in energy balance and body composition at menopause: a controlled longitudinal study. Ann Intern Med (1995) 123:673-5. doi:10.7326/0003-4819-123-9-199511010-00005

60. Lee JY, Takahashi N, Yasubuchi M, Kim YI, Hashizaki H, Kim MJ, et al. Triiodothyronine induces UCP-1 expression and mitochondrial biogenesis in human adipocytes. Am J Physiol Cell Physiol (2012) 302:C463-72. doi:10.1152/ajpcell.00010.2011

61. Rodriguez-Cuenca S, Monjo M, Gianotti M, Proenza AM, Roca P. Expression of mitochondrial biogenesis-signaling factors in brown adipocytes is influenced specifically by 17beta-estradiol, testosterone, and progesterone. Am J Physiol Endocrinol Metab (2007) 292:E340-6. doi:10.1152/ajpendo.00175.2006

62. Rodriguez AM, Monjo M, Roca P, Palou A. Opposite actions of testosterone and progesterone on UCP1 mRNA expression in cultured brown adipocytes. Cell Mol Life Sci (2002) 59:1714-23. doi:10.1007/PL00012499

63. Slavin BG, Elias JJ. Morphologic changes in white and brown adipose tissue by insulin, thyroxin and cortisol in organ culture. Anat Rec (1970) 167:213-8. doi:10.1002/ar.1091670209

64. Qiu Y, Nguyen KD, Odegaard JI, Cui X, Tian X, Locksley RM, et al. Eosinophils and type 2 cytokine signaling in macrophages orchestrate development of functional beige fat. Cell (2014) 157:1292-308. doi:10.1016/j.cell.2014.03.066

65. Bostrom P, Wu J, Jedrychowski MP, Korde A, Ye L, Lo JC, et al. A PGC1-alphadependent myokine that drives brown-fat-like development of white fat and thermogenesis. Nature (2012) 481:463-8. doi:10.1038/nature10777

66. Fisher FM, Kleiner S, Douris N, Fox EC, Mepani RJ, Verdeguer F, et al. FGF21 regulates PGC-1alpha and browning of white adipose tissues in adaptive thermogenesis. Genes Dev (2012) 26:271-81. doi:10.1101/gad.177857.111

67. Schulz TJ, Huang P, Huang TL, Xue R, McDougall LE, Townsend KL, et al. Brown-fat paucity due to impaired BMP signalling induces compensatory browning of white fat. Nature (2013) 495:379-83. doi:10.1038/nature11943

68. Rao RR, Long JZ, White JP, Svensson KJ, Lou J, Lokurkar I, et al. Meteorin-like is a hormone that regulates immune-adipose interactions to increase beige fat thermogenesis. Cell (2014) 157:1279-91. doi:10.1016/j.cell.2014.03.065

69. Keating SE, Hackett DA, George J, Johnson NA. Exercise and non-alcoholic fatty liver disease: a systematic review and meta-analysis. J Hepatol (2012) 57:157-66. doi:10.1016/j.jhep.2012.02.023
70. Matsuzawa Y. The role of fat topology in the risk of disease. Int J Obes (Lond) (2008) 32(Suppl 7):S83-92. doi:10.1038/ijo.2008.243

71. Ismail I, Keating SE, Baker MK, Johnson NA. A systematic review and metaanalysis of the effect of aerobic vs. resistance exercise training on visceral fat. Obes Rev (2012) 13:68-91. doi:10.1111/j.1467-789X.2011.00931.x

72. Cannon B, Nedergaard J. Brown adipose tissue: function and physiological significance. Physiol Rev (2004) 84:277-359. doi:10.1152/physrev.00015.2003

73. Cannon B, Jacobsson A, Rehnmark S, Nedergaard J. Signal transduction in brown adipose tissue recruitment: noradrenaline and beyond. Int J Obes Relat Metab Disord (1996) 20(Suppl 3):S36-42.

74. Ye L, Wu J, Cohen P, Kazak L, Khandekar MJ, Jedrychowski MP, et al. Fat cells directly sense temperature to activate thermogenesis. Proc Natl Acad Sci U S A (2013) 110:12480-5. doi:10.1073/pnas.1310261110

75. Carey DG, Jenkins AB, Campbell LV, Freund J, Chisholm DJ. Abdominal fat and insulin resistance in normal and overweight women: direct measurements reveal a strong relationship in subjects at both low and high risk of NIDDM. Diabetes (1996) 45:633-8. doi:10.2337/diab.45.5.633

76. Ross R, Aru J, Freeman J, Hudson R, Janssen I. Abdominal adiposity and insulin resistance in obese men. Am J Physiol Endocrinol Metab (2002) 282:E657-63. doi:10.1152/ajpendo.00469.2001

77. Lysaght J, Van Der Stok EP, Allott EH, Casey R, Donohoe CL, Howard JM, et al. Pro-inflammatory and tumour proliferative properties of excess visceral adipose tissue. Cancer Lett (2011) 312:62-72. doi:10.1016/j.canlet. 2011.07.034

78. Mathieu P, Boulanger MC, Despres JP. Ectopic visceral fat: a clinical and molecular perspective on the cardiometabolic risk. Rev Endocr Metab Disord (2014) 15:289-98. doi:10.1007/s11154-014-9299-3

79. Galic S, Oakhill JS, Steinberg GR. Adipose tissue as an endocrine organ. $\mathrm{Mol}$ Cell Endocrinol (2010) 316:129-39. doi:10.1016/j.mce.2009.08.018

80. Hocking SL, Wu LE, Guilhaus M, Chisholm DJ, James DE. Intrinsic depot-specific differences in the secretome of adipose tissue, preadipocytes, and adipose tissue-derived microvascular endothelial cells. Diabetes (2010) 59:3008-16. doi:10.2337/db10-0483

81. Van Harmelen V, Reynisdottir S, Eriksson P, Thorne A, Hoffstedt J, Lonnqvist F, et al. Leptin secretion from subcutaneous and visceral adipose tissue in women. Diabetes (1998) 47:913-7. doi:10.2337/diabetes.47.6.913

82. Wajchenberg BL. Subcutaneous and visceral adipose tissue: their relation to the metabolic syndrome. Endocr Rev (2000) 21:697-738. doi:10.1210/edrv.21. 6.0415

83. Lihn AS, Bruun JM, He G, Pedersen SB, Jensen PF, Richelsen B. Lower expression of adiponectin mRNA in visceral adipose tissue in lean and obese subjects. Mol Cell Endocrinol (2004) 219:9-15. doi:10.1016/j.mce.2004.03.002

84. Weyer C, Funahashi T, Tanaka S, Hotta K, Matsuzawa Y, Pratley RE, et al. Hypoadiponectinemia in obesity and type 2 diabetes: close association with insulin resistance and hyperinsulinemia. J Clin Endocrinol Metab (2001) 86:1930-5. doi:10.1210/jcem.86.5.7463

85. Cote M, Mauriege P, Bergeron J, Almeras N, Tremblay A, Lemieux I, et al. Adiponectinemia in visceral obesity: impact on glucose tolerance and plasma lipoprotein and lipid levels in men. J Clin Endocrinol Metab (2005) 90:1434-9. doi:10.1210/jc.2004-1711

86. Forouhi NG, Sattar N, Mckeigue PM. Relation of C-reactive protein to body fat distribution and features of the metabolic syndrome in Europeans and South Asians. Int J Obes Relat Metab Disord (2001) 25:1327-31. doi:10.1038/sj.ijo.0801723

87. Pou KM, Massaro JM, Hoffmann U, Vasan RS, Maurovich-Horvat P, Larson $\mathrm{MG}$, et al. Visceral and subcutaneous adipose tissue volumes are crosssectionally related to markers of inflammation and oxidative stress the Framingham heart study. Circulation (2007) 116:1234-41. doi:10.1161/ CIRCULATIONAHA.107.710509

88. Bruun JM, Lihn AS, Pedersen SB, Richelsen B. Monocyte chemoattractant protein-1 release is higher in visceral than subcutaneous human adipose tissue (AT): implication of macrophages resident in the AT. J Clin Endocrinol Metab (2005) 90:2282-9. doi:10.1210/jc.2004-1696

89. Wellen KE, Hotamisligil GS. Inflammation, stress, and diabetes. J Clin Invest (2005) 115:1111-9. doi:10.1172/JCI25102

90. Asterholm IW, Tao C, Morley TS, Wang QA, Delgado-Lopez F, Wang ZV, et al. Adipocyte inflammation is essential for healthy adipose tissue expansion and remodeling. Cell Metab (2014) 20:103-18. doi:10.1016/j.cmet.2014.05.005 
91. Cinti S, Mitchell G, Barbatelli G, Murano I, Ceresi E, Faloia E, et al. Adipocyte death defines macrophage localization and function in adipose tissue of obese mice and humans. J Lipid Res (2005) 46:2347-55. doi:10.1194/jlr.M500294JLR200

92. Strissel KJ, Stancheva Z, Miyoshi H, Perfield JW II, Defuria J, Jick Z, et al. Adipocyte death, adipose tissue remodeling, and obesity complications. Diabetes (2007) 56:2910-8. doi:10.2337/db07-0767

93. Fried SK, Leibel RL, Edens NK, Kral JG. Lipolysis in intraabdominal adipose tissues of obese women and men. Obes Res (1993) 1:443-8. doi:10.1002/j.15508528.1993.tb00026.x

94. Lemieux S, Despres JP. Metabolic complications of visceral obesity contribution to the etiology of type-2 diabetes and implications for prevention and treatment. Diabete Metab (1994) 20:375-93.

95. Arner P. Differences in lipolysis between human subcutaneous and omental adipose tissues. Ann Med (1995) 27:435-8. doi:10.3109/07853899709002451

96. Fried SK, Tittelbach T, Blumenthal J, Sreenivasan U, Robey L, Yi J, et al. Resistance to the antilipolytic effect of insulin in adipocytes of AfricanAmerican compared to Caucasian postmenopausal women. J Lipid Res (2010) 51:1193-200. doi:10.1194/jlr.P000935

97. Ibrahim MM. Subcutaneous and visceral adipose tissue: structural and functional differences. Obes Rev (2010) 11:11-8. doi:10.1111/j.1467-789X.2009. 00623.x

98. Bjorntorp P. Portal adipose-tissue as a generator of risk-factors for cardiovascular-disease and diabetes. Arteriosclerosis (1990) 10:493-6. doi:10. 1161/01.ATV.10.4.493

99. Boden G. Role of fatty acids in the pathogenesis of insulin resistance and NIDDM. Diabetes (1997) 46:3-10. doi:10.2337/diab.46.1.3

100. Seppala-Lindroos A, Vehkavaara S, Hakkinen AM, Goto T, Westerbacka J, Sovijarvi A, et al. Fat accumulation in the liver is associated with defects in insulin suppression of glucose production and serum free fatty acids independent of obesity in normal men. J Clin Endocrinol Metab (2002) 87:3023-8. doi:10.1210/jcem.87.7.8638

101. Virkamaki A, Korsheninnikova E, Seppala-Lindroos A, Vehkavaara S, Goto $\mathrm{T}$, Halavaara J, et al. Intramyocellular lipid is associated with resistance to in vivo insulin actions on glucose uptake, antilipolysis, and early insulin signaling pathways in human skeletal muscle. Diabetes (2001) 50:2337-43. doi:10.2337/diabetes.50.10.2337

102. Klein S. The case of visceral fat: argument for the defense. J Clin Invest (2004) 113:1530-2. doi:10.1172/JCI200422028

103. Nielsen S, Guo Z, Johnson CM, Hensrud DD, Jensen MD. Splanchnic lipolysis in human obesity. J Clin Invest (2004) 113:1582-8. doi:10.1172/JCI21047

104. Huang-Doran I, Sleigh A, Rochford JJ, O’Rahilly S, Savage DB. Lipodystrophy: metabolic insights from a rare disorder. J Endocrinol (2010) 207:245-55. doi:10.1677/JOE-10-0272

105. Carr A, Samaras K, Thorisdottir A, Kaufmann GR, Chisholm DJ, Cooper DA. Diagnosis, prediction, and natural course of HIV-1 protease-inhibitorassociated lipodystrophy, hyperlipidaemia, and diabetes mellitus: a cohort study. Lancet (1999) 353:2093-9. doi:10.1016/S0140-6736(98)08468-2

106. Kadowaki T, Yamauchi T. Adiponectin and adiponectin receptors. Endocr Rev (2005) 26:439-51. doi:10.1210/er.2005-0005

107. Van De Vyver M, Andrag E, Cockburn IL, Ferris WF. Thiazolidinedioneinduced lipid droplet formation during osteogenic differentiation. J Endocrinol (2014) 223:119-32. doi:10.1530/JOE-14-0425

108. Klein S, Fontana L, Young VL, Coggan AR, Kilo C, Patterson BW, et al. Absence of an effect of liposuction on insulin action and risk factors for coronary heart disease. N Engl J Med (2004) 350:2549-57. doi:10.1056/NEJMoa033179
109. Gabriely I, Ma XH, Yang XM, Atzmon G, Rajala MW, Berg AH, et al. Removal of visceral fat prevents insulin resistance and glucose intolerance of aging: an adipokine-mediated process? Diabetes (2002) 51:2951-8. doi:10.2337/diabetes. 51.10 .2951

110. Klein S. Is visceral fat responsible for the metabolic abnormalities associated with obesity?: implications of omentectomy. Diabetes Care (2010) 33:1693-4. doi: $10.2337 / \mathrm{dc} 10-0744$

111. Molero JC, Turner N, Thien CB, Langdon WY, James DE, Cooney GJ. Genetic ablation of the c-Cbl ubiquitin ligase domain results in increased energy expenditure and improved insulin action. Diabetes (2006) 55:3411-7. doi:10.2337/db06-0955

112. Kim DH, Sartor MA, Bain JR, Sandoval D, Stevens RD, Medvedovic M, et al. Rapid and weight-independent improvement of glucose tolerance induced by a peptide designed to elicit apoptosis in adipose tissue endothelium. Diabetes (2012) 61:2299-310. doi:10.2337/db11-1579

113. Lemoine AY, Ledoux S, Larger E. Adipose tissue angiogenesis in obesity. Thromb Haemost (2013) 110:661-8. doi:10.1160/TH13-01-0073

114. Gesta S, Tseng YH, Kahn CR. Developmental origin of fat: tracking obesity to its source. Cell (2007) 131:242-56. doi:10.1016/j.cell.2007.10.004

115. Lee KY, Yamamoto Y, Boucher J, Winnay JN, Gesta S, Cobb J, et al. Shox2 is a molecular determinant of depot-specific adipocyte function. Proc Natl Acad Sci US A (2013) 110:11409-14. doi:10.1073/pnas.1310331110

116. Van Der Lans AA, Hoeks J, Brans B, Vijgen GH, Visser MG, Vosselman MJ, et al. Cold acclimation recruits human brown fat and increases nonshivering thermogenesis. J Clin Invest (2013) 123:3395-403. doi:10.1172/JCI68993

117. Yoneshiro T, Aita S, Matsushita M, Kayahara T, Kameya T, Kawai Y, et al. Recruited brown adipose tissue as an antiobesity agent in humans. JClin Invest (2013) 123:3404-8. doi:10.1172/JCI67803

118. Lee P, Smith S, Linderman J, Courville AB, Brychta RJ, Dieckmann W, et al. Temperature-acclimated brown adipose tissue modulates insulin sensitivity in humans. Diabetes (2014) 63:3686-98. doi:10.2337/db14-0513

119. Redman LM, De Jonge L, Fang X, Gamlin B, Recker D, Greenway FL, et al. Lack of an effect of a novel beta3-adrenoceptor agonist, TAK-677, on energy metabolism in obese individuals: a double-blind, placebo-controlled randomized study. J Clin Endocrinol Metab (2007) 92:527-31. doi:10.1210/jc.2006-1740

120. Lee P, Linderman JD, Smith S, Brychta RJ, Wang J, Idelson C, et al. Irisin and FGF21 are cold-induced endocrine activators of brown fat function in humans. Cell Metab (2014) 19:302-9. doi:10.1016/j.cmet.2013.12.017

Conflict of Interest Statement: The authors declare that the research was conducted in the absence of any commercial or financial relationships that could be construed as a potential conflict of interest.

Received: 23 October 2014; accepted: 07 January 2015; published online: 30 January 2015.

Citation: Ma X, Lee P, Chisholm DJ and James DE (2015) Control of adipocyte differentiation in different fat depots; implications for pathophysiology or therapy. Front. Endocrinol. 6:1. doi: 10.3389/fendo.2015.00001

This article was submitted to Experimental Endocrinology, a section of the journal Frontiers in Endocrinology.

Copyright (C) 2015 Ma, Lee, Chisholm and James. This is an open-access article distributed under the terms of the Creative Commons Attribution License (CC BY). The use, distribution or reproduction in other forums is permitted, provided the original author(s) orlicensor are credited and that the original publication in this journal is cited, in accordance with accepted academic practice. No use, distribution or reproduction is permitted which does not comply with these terms. 